\title{
SUSTAINABLE DEVELOPMENT STRATEGIES FOR RURAL AREAS IN NASARAWA STATE, NIGERIA
}

\section{Sylvester Umbugadu Aku' ${ }^{1}$ and Danjuma Naisla Hassan ${ }^{2}$}

\author{
${ }^{1}$ Department of Accountancy, Nasarawa State Polytechnic, Lafia, Nasarawa State, Nigeria. \\ Email: umbugaku@gmail.com; Tel: 08034165070
}

${ }^{2}$ Department of General Studies, Nasarawa State Polytechnic, Lafia, Nasarawa State, Nigeria. Email: naisladan@yahoo.com; Tel: 08034443571

\section{Cite this article:}

Sylvester U.A., Danjuma N.H. (2021), Sustainable

Development Strategies for Rural Areas in Nasarawa

State, Nigeria. African Journal of Economics and Sustainable Development 4(1), 63-80. DOI: $10.52589 / A J E S D-$ YPUFI4NU.

\section{Manuscript History \\ Received: 10 May 2021 \\ Accepted: 28 May 2021}

Published: 12 June 2021

Copyright @ 92020 The Author(s). This is an Open Access article distributed under the terms of Creative Commons AttributionNonCommercial-NoDerivatives 4.0 International (CC BY-NC-ND 4.0 ), which permits anyone to share, use, reproduce and redistribute in any medium, provided the original author and source are credited.
ABSTRACT: Sustainable development is a new concept in development economics that needs not to be limited to towns and cities in developing economies like Nigeria. This study therefore examined the strategies for promoting sustainable development in Nasarawa State. The study was guided by cross-section survey design. A sample size of 400 respondents was selected from three rural areas in the State using simple random sampling techniques. A structured questionnaire designed by the researchers was used as instrument for data collection. The instrument was validated by experts and its reliability was ascertained using the Cronbach Alpha Coefficient technique. Descriptive statistics, principally, simple percentages, mean and standard deviation were used for data analysis. The findings revealed that agricultural development and social services provisions have been the major rural development strategies adopted in the State that have been implemented in the State. The results also showed that less attention has been given to human capital development, political inclusion, infrastructural development and industrial growth. It was found that radio and television, farmers and traders association and collaboration with traditional councils are ways of creating awareness on sustainable rural development. However, exclusion of rural $d w e l l e r s$ at the planning stage and absence of rural needs assessment were found to be the major challenges to sustainable rural development. The study revealed that employing contractors of projects from communities where projects are sited and the need to plan based rural realities can enhance rural dwellers involvement in sustainable rural development decisions. The study concluded that strategies for sustainable rural development in Nasarawa State have not been effectively designed and implemented because the emphasis has always been on agriculture. The study recommended that Government should always embark on rural development needs assessment, sustainable rural development should emphasis the bottom-top approach, greater investment in human capital and rural entrepreneurial initiatives.

KEYWORDS: Strategies, Rural Development, Sustainable Development, Sustainable Rural Development 


\section{INTRODUCTION}

The rural areas are communities where the vast population resides, especially in developing countries like Nigeria being agrarian society where agricultural products are produced. There is need for a sustainable development policy that will harness the resources to improve the lives of people in rural areas as well as the socio-economic growth of the economy in general. Though it is a well-known fact that in Nigeria different governments have over the years embarked on various development projects in various communities in the state, most of these projects are either not completed, abandoned or not functional despite monetary expenditure made on them. In most cases also, some of these projects planned for execution in rural communities are not even the major need of the communities. Rural areas are generally recognized as important in the areas of agricultural production and employment in Africa (Raheem\& Bako, 2014). Many developing countries, including Nigeria have long suffered due to the failure of governments at all levels to adopt sustainable development strategies as their model for development. This challenge has led the increasing macroeconomic problems like rising levels of poverty, unemployment and underemployment with the rural areas worstoff.

Therefore, tackling these challenges as a way of for ensuring economic growth and development surely calls for adoption of a multi-faceted development approach. This strategy should have the capacity to successfully combine both macro-and micro-economic interventions besides empowerment of people and local institutions for addressing both the quality life of rural dwellers and the increasing challenge of rural under-development. The concept of development has been described as a process by which man increases or maximizes his control and use of the material resources with which nature has endowed him and his environment. Hence, in pursuing the sustainable development agenda, there is need for the re-orientation and strengthening of the national architecture for public governance as well as participatory democratic approaches for the rural people in the governance of their country.

Most rural dwellers in States like Nasarawa State are engaged in and depend on local agriculture, forestry, and fishery resources to make a living. The rural sector is still largely characterized by absence of basic human needs and underdevelopment in agricultural and non-agricultural activities (Williams, 1994). It is important to note that rural development is a process of not only increasing the level of per capita income in the rural areas but also the standard of living of the rural population measured by food and nutrition level, health, education, housing, recreation and security among others. The emphasis on sustainable rural development is on the people and the environment. It suggests that rural development strategies should not be limited to the needs of the present generation alone; it should as well consider the need of the future generation of rural dwellers and the protection of the environment for sustainable impacts. Consequently, Laahet'al., (2013) opined that rural development demands attention if the living condition of people is to improve particularly those in the rural areas.

The understanding of the rural development as a concept and its principles will afford the policy makers, especially the State Government the opportunity to collaborate with other stakeholders in order to come up with all-encompassing sustainable rural development agenda for the rural people. These policies should among other basic needs aimed at addressing the alarming rate of poverty which is higher in rural communities is higher than 
the urban areas. Awojobi (2014)stated that there is the need of the political will on the side of the government, stakeholders and development agencies to initiate a holistic and rural development strategy to fight poverty in the rural areas. Although, governments have initiated some rural development programmes, but have failed woefully in limiting the developmental imbalance that exists between rural and urban areas in most States in Nigeria. Nalere, Yago and Kenny (2015) conducted a study on the contribution of rural institutions to rural development: Study of smallholder farmer groups and NGOs in Uganda and found that rural development can be achieved through improvements in health, education, agriculture and rural industry in rural areas of Uganda. This study was delimited to what institutions can do to promote rural development in Uganda, not of strategies for rural development in Nasarawa State, Nigeria. It is against this background that this study centred on strategies for rural development in Nasarawa State, Nigeria.

\section{Statement of the Problem}

Every urban area was at a point called a rural area. This therefore means that what differentiates a rural area from an urban area is principally its level of development measured in terms of the availability of social, economic and political institutions. The importance of developing rural areas remained one of the major reasons why various governments have embarked on development projects in communities in the state. Most of these programmes failed to see the light of the day partly because the rural poor were excluded at the policy formulation phase thereby paving way for the provision of programmes that are not even the major need of the rural communities; hence find it extremely difficult for them to take ownership of such programmes.

The early years of Nigeria's independence also witnessed colossal concentration of development efforts on the modern sector of the economy, however, to the exclusion of investment in the rural economic base. Abraham and Balogun (2012) argued that the Peoples Bank branches were located in some regions for political reasons and not because they are important in their localization. The problem has been how to develop rural areas both in terms of economic and human resources. In Nasarawa State, a number of rural development strategies have been pursued by successive governments. Most of these programmes seem to have been concentrated on the provision of roads to some communities, provision of loans to civil servants in rural areas, capacity building institutions. In attempt to curb this challenge also, the government of Nasarawa State have established of rice and Garri processing plants in some rural areas and provided subsidy on fertilizer for farmers. Sadly, the conditions of the peasantry and rural communities in recent years have consistently worsened or deteriorated as more and more rural development programmes and strategies have been unfolded by successive governments in the State. This constitutes a challenge despite the introduction of the Nigerian government National Policy on Integrated Rural Development or the Nigeria's Rural Development Policy for Sustainable Growth. The general consensus in literature is that most of these well-articulated rural development programmes in Nigeria have not been sustainable, partly because, once the tenure of the administration expires; the policy also ends, no matter how good they may be. Sustainable rural development related issues have attracted the attention of Scholars like; Awojobi (2014); Akintoye and Opeyemi (2014) and Raheem and Bako (2014) among others have conducted studies on sustainable development as it relates to rural development, but with variations in their findings. The variations in these studies may be attributed to issues such as variables captured, study setting and methodological issues such as the research design, type of data used and instruments for data 
collection among others. More so, none of these studies concentrated on strategies for promoting sustainable rural development in Nasarawa State. The major problem that prompted this study therefore is; what are the most effective strategies for promoting sustainable rural development in Nasarawa State?

\section{Objectives of the Study}

The purpose of this study is to examine the strategies for sustainable rural development in Nasarawa State. Specifically, the study seeks to achieve the following objectives:

1. To determine the extent to which strategies for sustainable rural development are implemented by the government of Nasarawa State?

2. To examine the strategies for creating awareness on the need to have a workable blue print for sustainable development of the rural areas in Nasarawa State?

3. To find out the challenges to sustainable rural development in Nasarawa State?

4. To evaluate ways in which communities can be involved in sustainable rural development decisions in Nasarawa State?

5. To find out the workable blue plans necessary for sustainable rural development in Nasarawa State?

\section{Research Questions}

To successfully collect the needed data for the study, the following questions were used guides:

1. What has been the extent of implementation of rural development strategies in Nasarawa State?

2. What are the strategies for creating awareness on the need to have a workable blue print for sustainable development of the rural areas in Nasarawa State?

3. What are the difficulties faced by the state government in developing rural areas in Nasarawa State?

4. What are the ways in which communities can be involved in rural development decisions in Nasarawa State?

5. What are the workable blue plans necessary for sustainable rural development in Nasarawa State? 


\section{REVIEW OF LITERATURE}

\section{Concept of Rural Development}

One major characteristic of developing countries including Nigeria is the increasing disparity in terms of standard of living between the urban and rural areas.Development as a concept goes beyond economic growth because it captures the living conditions of the people. The concept involves changes in institutions, outputs and standard of living of the better, whether in rural or urban communities. Rural development is centrally focused on organizing human and natural resources designed to provide a solution to the perennial problems of poverty and deprivation of rural folks with a view of raising their living conditions (Oluseyi,2018). Herman (2017) had noted that the development is rooted in the neo classical economic theories which presumes that development can be accelerated by concentrating investment in the cities and that rural poverty can be ameliorated by the trickled down of benefit from urban industrial growth.According to Mirikhor and Askari (2010), development means quantitative growth, qualitative improvement, and expansion in the capabilities, capacities, and choice of individual groups or state.

Rural development is a comprehensive and multidimensional concept that encompasses the development of agriculture and allied activities -village and cottage industries and crafts, socio-economic infrastructure, community services and facilities, and above all, the human resources in rural areas. Todaro (2008) asserted that rural development encompasses; improvement in level of living including employment, education, health and nutrition, housing and variety of social services; decreasing inequalities in the distribution of rural incomes and in rural urban balances in income and economic opportunities and the capacity of the rural sector to sustain and accelerate the pace of improvements. The critical element in rural development from this definition is improvement of living standards of the poor through opportunities for better utilization of their physical and human resources.

Many have defined rural development in terms of the quantitative indices of development that cut across social, economic, institutions and political spheres of human life. In this case, rural development centres of the availability and quality of educational institutions, healthcare facilities, water supply, electricity, good roads, quality of accommodation or shelter, commercial activities, industrial growth and other factors needed for decent living in rural communities. Laahet'al. (2013) defined rural development as the product of various quantitative and qualitative changes in the midst of a rural population and whose converging impacts indicate, in time, an increase in the standard of living and favourable changes in the way of life of the people concerned.

In Nigeria, a wide gap exists in the development levels of urban and rural areas. This seems to be threatening the political and social stability of the country. This is true because despite having the overwhelming proportion of the national population, the rural areas are characterized by pervasive and endemic poverty, manifested by hunger, malnutrition, poor health, inadequate access to formal education, livable housing and various forms of social amenities compared to their urban counterparts. It is important to re-echo that the problems of the urban centers cannot be solved unless those of the rural areas are solved, or at least contained because most of these challenges emanated from the unprecedented rural-urban migration which in turn derives from rural stagnation or under development, poverty and unemployment. It is in the light of this that Oluseyi (2018) maintained that rural 
development is directed at both getting the migrants back to the rural areas and preventing further streams of migrants from leaving the rural areas.

Rural development therefore should be viewed from a quantitative perspective which hitherto has being the cases in most societies; it should define in clear terms what happens to the quality of lives of the rural dwellers. Thus, it can be argued that a combination of both the qualitative and quantitative improvement in the conditions of living of rural population stands out the best description of sustainable rural development. Rural infrastructure has over time suffered neglect in quality and quantity and its distribution is heavily skewed in favor of the growing urban areas. Adenipekun (2010) held the view that the exploitation of natural resource endowments in the rural areas will go a long way in producing sufficient capital for rural development projects in Nigeria. The author added that the benefit of their natural geographical spreads across the length and breadth of the entire country in commercial quantities will sustainably last generations, but the conservation of these resource reserves remains the big challenges in rural development initiatives in Nigeria. This implies that for rural development to be sustainable, the available natural resources in each rural area should be effectively harnessed in an eco-friendly manner so as to protect the environment to ensure sustainability in the production of the resources.

According to Nyagba (2012), the rural population represents an average of over 60 percent of the total population on the continent; about 90 percent of the rural labour engages directly or indirectly in agricultural activities. For the continent's rural people, accelerated agricultural and rural development would contribute to greater efficiency, increased household income, improved standards of living, and poverty reduction. In Nigeria, it is an established fact that the continuous neglect of the rural communities by successive governments has made the rural-urban drift intensified. Olayiwola and Adeleye (2005) posited that the lack of basic amenities in rural communities has made life difficult for graduates of rural post-primary schools. Most of the rural areas in Nigeria are predominantly agricultural communities

The policy objectives of the National Policy of Integrated Rural Development draws from the national objectives of developing the rural areas, raising the quality of life of the rural people, alleviating rural poverty and using rural development to contribute to laying a solid foundation for national development. Nyagba (2012) stated that,though the strategies of the policy are to achieve integrated and even development on a sustainable basis, the strategies to be adopted will empower rural dwellers through the development of productive employment, enhancing their income, ensuring protection of the environment, promoting gender responsiveness and ensuring adequate care for vulnerable groups. Rural development documents embrace a comprehensive approach to the conceptualization of sustainability that involves environmental, economic and social dimensions (Cawley\&Gillmo, 2008).

The development of infrastructure is integral to the development of rural areas. According to Olaseni and Alade (2012) infrastructure is an umbrella term for many activities usually referred to as social overhead capital needed for development. Rural infrastructure is associated with the rural environments consist of economic, social and institutional infrastructures. These, infrastructural facilities that need to be developed in rural communities are roads, transportation, communications, power supplies, water supplies, public services, broadcasting and telecommunications. This implies that for meaningful rural development, critical infrastructures should be provided in all rural areas. 
The concept of sustainable rural development as an alternative strategy to overall development has become a worldwide concern in both the advanced and developing countries where States policy or programme has not touched or had direct bearing on the rural sector. The concept of Sustainable development defined sustainable rural development as the "improving the quality of life for the rural people by developing capacities that promote community participation, health and education, food security, environmental protection and sustainable growth, thereby enabling community members to leave the cycle of poverty and achieve their full potential.

According to Wilkin (2010), the context of sustainable development is the new focus and functions of rural areas which include:

Green functions: management of green resources to keep it in good condition, including good condition for animals,

Blue functions: management of water resources, improving water quality, flood prevention, and water and wind energy production,

Yellow functions: keeping cohesion of healthy and rural areas, keeping and enhancing cultural tradition of agri-tourism development and

White functions: this deal with the issue of food security and healthy food

\section{Review of Rural Development Strategies Adopted in Nigeria}

Rural development has been distorted in meaning and content in Nigeria. It has been perceived as a strategy mainly related to agricultural productivity and primarily tied to economic growth. It can be infer that the thinking amongst the policy makers in Nigeria is that increased agricultural productivity could solve the developmental problems of rural communities and rural dwellers.

According to Adenipekun (2013), realizing the gap between rural-urban sectors, successive governments in the country began to put various programmes in place to meet both the national and international goals of human and capital developments. The government launched different plans targeted at promoting development, including rural development. These plans focused on issues such as agriculture because agricultural productivity is synonymous to rural development, rural infrastructures as means of facilitating the movement of cash crop from rural; and urban areas, creation rural employment opportunities as a way of curbing rural-urban migration and improving the quality of social services, integrated rural development strategy through the Agricultural Developments Projects and promotion of rural economic activities. Akpomuvie(2010) pointed out that the low level of infrastructural and human capital development in the rural areas is a clear sign of weakness and ineffectiveness of these programmes and schemes. Therefore, for Nigeria to address the underlying problem of sustainable economic development which is now the target of most economies in the world, the issue of rural development must properly be taken care of because every urban dweller comes from rural area and a bulk of what is consume in urban areas are produced in rural areas. 


\section{Sustainable Rural Development and Sustainable Rural Development Strategies}

The magnitude of social disparities in primary education, geographical location and family income and absence and mismanagement of our abundant natural resources like land and water in the context of any development initiative poses a lot of challenges for the policymakers both at the policy planning and implementation level as well. The rural regions not only suffers from lack of awareness about the advanced way of producing agricultural crops and little on the livestock, fisheries and allied forests sectors even though these sectors have been known to play a central part of food supply as well as an important source of income in our rural areas.

Sustainable rural development does not mean a return to a pre-industrial era, but calls for continued economic growth, with business and industry acknowledging and taking responsibility for their impact on society and the environment (Mohapatra, 2015). Sustainable development can also be viewed as a process of achieving economic and social development in ways that do not exhaust a country's natural resources. Sustainable development therefore is a process of change in which the exploitation of resources, the direction of investments, the orientation of technological development, and institutional change are made consistent with the future as well as present needs". It advocates for use of an area within our capacity to sustain its cultural or natural significance, and ensure that the benefits of the use to present generations do not diminish the potential to meet the needs and aspirations of future generations.

Sustainable rural development strategy implies that any developmental plan of the government that is targeted at rural communities must take into cognizance the needs of the present generation of rural dwellers without in any way hampering the future needs of rural communities. According to Akpomuvie (2010), rural development on a sustainable basis should move away from a condition of life that is widely perceived as sub-standard as experienced in the rural areas and towards condition of life regarded as materially and spiritually better. The social components of sustainable development also set to achieve equity in social issues as education, health politics and social infrastructures. To achieve sustainable social development in rural areas, there is need for the creation of new employment opportunities for young school learners and rural dwellers; institutions of governance at all levels should be strengthen to prevent abuse of people rights and conflicts. Sustainable environmental development focuses on environmental protection especially now that technological development has impacted negatively on land and water resources thereby exposing communities, mostly rural dwellers to environmental pollution and degradation and sustainable economic development as an aspect of sustainable development involves achieving a balance in all sectors of the economy in the process of production of goods and services.

According to the World Bank (2011), to promote sustainable rural development there is need for increasing local communities' and groups involvement decision making; building on local knowledge and traditions for resource management as an opportunity to initiate longer term development; and improving vertical and horizontal institutional linkages and building strategic and technical partnerships with external partners within the identified framework for complementary action. This is critical because the main policy trust of sustainable development is that the environment should be seen as an asset, a stock of available wealth but if the present generation spends this wealth without investment for the future then the 
world will run out of resources. It was then suggested that to achieve sustainable rural development, there is the need for the adoption of the participatory rural appraisal development strategy. This model put the local people (dwellers) majorly at the centre of development programmes and policies of the government. In this case, the development planners or researchers go to the villages more as learners, catalysts, and facilitators to find out the pressing needs of the people so as to uncover local knowledge and understanding. The aim of this strategy is to enable rural people to do their own investigations, share their knowledge and teach others to do the analysis and presentations, to plan and to own the outcome. This approach has the advantages of gathering, analyzing and delivering rural development information that is timely, cost effective, accurate and contextual. This implies that the model is not only community driven, but it is also insightful and highly useful as basis for sustainable rural development planning. In order to avoid this situation, local decision-making in project planning and implementation is important. In other words, a project that the local people themselves plan and implement is given priority as local materials and human resources are utilized effectively by the local people's initiative and responsibility.

The tickle-down development approach should also be considered and applied as a strategy for sustainable rural development in the State. The trickle-down theory is based on the assumption that an expanded macro economy could improve the living standards of impoverished people. However, this does not necessarily mean that efforts should be concentrated at the grass-roots level only. This is because the development of rural areas cannot be achieved without attention to urban areas, which are the main consumers of agricultural products. This implies that if conventional development projects were effective, rural development would have improved more significantly. Therefore, it is clear that the traditional rural development approach needs to be improved. Rural development issues must therefore be comprehensively understood in such a way that what is provided to urban areas as incentives for development should be extended to rural areas on a sustainable basis.

The humanistic approach to rural development is an important model that can be adopted in the State. This model is purely educational programme concerned with consciousness raising and empowerment. A humanistic approach to development maintains that by heightening or changing man's ability to appreciate his own endowment will arm him with a new vision and a new tool with which to shape communal space and therefore, shape his life and his fortune. The theory focuses on the improvement of the society's capacity to understand, manage and control its environment; and merely to exploit it. It argues that self-consciousness which is a major tenet of the humanistic approach to development can bring about self-emancipation and make the rural dwellersexert sufficient control over their environment and its resources. By and large, Surchev (2010) stated that the most suitable approach to sustainable rural development would be the combination of both the state intervention and promoting the potential of local people.

\section{Theoretical Framework}

This study was hinged on the 'the integrated development model' and redefined as the integrated-local-endogenous development formulated by Christofakis (2001) due tothe organization of production, its interconnection with research and technological development, distribution, vocational training processes, development of new relations between corporations and local organizations, and the networking of sectors. The integrated -local- 
endogenous development model has a rural application. The model assumes that rural development strategies should focus more on ways of integrating urban and rural economy. Christofakis and Papadaskalopoulos (2011) argued that with the integrated model, settlements and dynamic cities would function in synergy to be able to focus and capture the growth and competitiveness as well as the prosperity desired for a region or the country at large. This model is considered relevant to this study on sustainable rural development owing to the fact that the policy trust of rural development that will be beneficial to the present generation, without limiting such benefits to the future generation at the same time ensuring that the environment is protected requires that both areas should be the focus of government.

\section{METHODOLOGY}

The study used descriptive survey design as a guide. This design was considered the most appropriate because the research aimed at assessing the problem as it exist in its physical setting using a sample of respondents. The study considered the 13 Local Government Areas that constitute the three senatorial zones in Nasarawa State as the target population. Thus, one community was selected randomly from each of the 3 senatorial districts of Nasarawa State is selected for this study. These include; Rutu in Doma local government (southern senatorial district), Ogba in Nassarawa-Eggon local government area (Northern senatorial district) and Yarkade in Keffi local government area (Western senatorial district). The study used primary data gathered through the use of interview. Considering the nature of the research which involves rural areas and other factors, the study was carried out within seven months.

The sample size of 400 respondents was randomly selected from the selected rural areas in the three senatorial zones of the State.Thus, a sample of 133 participants was selected each from Rutu and Ogba, while 134 were selected from Yarkade to constitute the sample community. The study participants were randomly selected from the various groups and gender comprising of elders, youths, students, businessmen and women, artisans, farmers, opinion leaders and government officials. A structured questionnaire was used for data collection. The content and face validity of the questionnaire was determine by experts, while its reliability coefficient of 0.871 was obtained using the Cronbach Alpha technique. Simple percentages mean and standard deviation were the descriptive statistics used for data analysis. A mean of 3.0, the average of the 5-point Likert scale was used as the criterion or decision mean. 


\section{RESULTS}

Table 1: Extent of Implementation ofSustainable Rural Development been

\begin{tabular}{|c|c|c|c|c|c|c|c|}
\hline SN. & $\begin{array}{l}\text { Sustainable Rural } \\
\text { Development Strategies }\end{array}$ & $\begin{array}{c}\text { TVLE } \\
(\%)\end{array}$ & $\begin{array}{l}\text { TLE } \\
(\%)\end{array}$ & $\begin{array}{l}\text { NS } \\
(\%)\end{array}$ & $\begin{array}{l}\text { TSE } \\
(\%)\end{array}$ & $\begin{array}{l}\text { TLTE } \\
(\%)\end{array}$ & $\overline{\mathbf{X}}$ \\
\hline 1 & Agricultural Development & $\begin{array}{c}262 \\
(65.5)\end{array}$ & $\begin{array}{c}67 \\
(16.8)\end{array}$ & $\begin{array}{c}24 \\
(6.0)\end{array}$ & $\begin{array}{c}24 \\
(6.0)\end{array}$ & $\begin{array}{c}23 \\
(5.8)\end{array}$ & 3.302 \\
\hline 2 & $\begin{array}{l}\text { Infrastructural } \\
\text { Development }\end{array}$ & $\begin{array}{c}26 \\
(6.5)\end{array}$ & $\begin{array}{c}82 \\
(20.5)\end{array}$ & $\begin{array}{c}11 \\
(2.8)\end{array}$ & $\begin{array}{c}261 \\
(65.3)\end{array}$ & $\begin{array}{c}20 \\
(5.0)\end{array}$ & 2.345 \\
\hline 3 & $\begin{array}{l}\text { Human Capital } \\
\text { Development }\end{array}$ & $\begin{array}{c}17 \\
(4.3)\end{array}$ & $\begin{array}{c}82 \\
(20.5)\end{array}$ & $\begin{array}{c}12 \\
(3.0)\end{array}$ & $\begin{array}{c}270 \\
(67.5)\end{array}$ & $\begin{array}{c}19 \\
(4.8)\end{array}$ & 2.418 \\
\hline 4 & $\begin{array}{l}\text { Environmental Resources } \\
\text { protection }\end{array}$ & $\begin{array}{c}25 \\
(6.3)\end{array}$ & $\begin{array}{c}59 \\
(14.8)\end{array}$ & $\begin{array}{c}30 \\
(7.5)\end{array}$ & $\begin{array}{c}264 \\
(66.0)\end{array}$ & $\begin{array}{c}22 \\
(5.5)\end{array}$ & 2.295 \\
\hline 5 & al inclusion & $\begin{array}{c}20 \\
(5.0)\end{array}$ & $\begin{array}{c}89 \\
(22.3)\end{array}$ & $\begin{array}{c}39 \\
(9.8)\end{array}$ & $\begin{array}{c}237 \\
(59.3)\end{array}$ & $\begin{array}{c}15 \\
(3.8)\end{array}$ & 2.283 \\
\hline 6 & Industrial growth & $\begin{array}{c}13 \\
(3.3)\end{array}$ & $\begin{array}{c}70 \\
(17.5)\end{array}$ & $\begin{array}{c}42 \\
(10.5)\end{array}$ & $\begin{array}{c}263 \\
(65.8)\end{array}$ & $\begin{array}{c}12 \\
(3.0)\end{array}$ & 2.398 \\
\hline 7 & $\begin{array}{l}\text { Poverty } \\
\text { reduction/economic } \\
\text { empowerment }\end{array}$ & $\begin{array}{c}17 \\
(4.3)\end{array}$ & $\begin{array}{c}93 \\
(23.3)\end{array}$ & $\begin{array}{c}29 \\
(7.2)\end{array}$ & $\begin{array}{c}252 \\
(63.0)\end{array}$ & $\begin{array}{c}9 \\
(2.3)\end{array}$ & 2.405 \\
\hline 8 & $\begin{array}{l}\text { Social services } \\
\text { development }\end{array}$ & $\begin{array}{c}57 \\
(14.2\end{array}$ & $\begin{array}{c}236 \\
(59.0)\end{array}$ & $\begin{array}{c}46 \\
(11.5)\end{array}$ & $\begin{array}{c}23 \\
(59.0)\end{array}$ & $\begin{array}{c}38 \\
(9.5) \\
\end{array}$ & 4.275 \\
\hline
\end{tabular}

The findings from the analysis of the extent of the implementation of sustainable rural development strategies in Table 1 revealed that agricultural development strategy ( $X=3.302$ ) and social services development ( $X=3.275$ ) are the major rural development strategies that have been implemented to a large extent in rural areas of Nasarawa State. The mean ratings for strategies like infrastructural Development, human capital development, environmental resources protection, political inclusion, industrial growth and poverty reduction/economic empowerment were less than 3.0 used as the mean for statistical decisions. This implies that to some extent these strategies have been adopted by its level of implementation has been insignificant in promoting development in rural areas.

Table 2: Ways of Creating Awareness on Strategies for Sustainable Rural Development

\begin{tabular}{llcccccc}
\hline SN. & $\begin{array}{l}\text { Ways of Creating } \\
\text { Awareness }\end{array}$ & $\begin{array}{c}\text { TVLE } \\
(\boldsymbol{\%})\end{array}$ & $\begin{array}{c}\text { TLE } \\
(\boldsymbol{\%})\end{array}$ & $\begin{array}{c}\text { NS } \\
(\boldsymbol{\%})\end{array}$ & $\begin{array}{c}\text { TSE } \\
(\boldsymbol{\%})\end{array}$ & $\begin{array}{c}\text { TLTE } \\
(\boldsymbol{\%})\end{array}$ & $\overline{\mathbf{X}}$ \\
\hline 1 & Public sensitization & 250 & 70 & 44 & 14 & 22 & 3.288 \\
& programmes & $(62.5)$ & $(17.5)$ & $(11.0)$ & $(3.5)$ & $(5.5)$ & \\
2 & Advocacy visits & 222 & 107 & 24 & 31 & 16 & 3.195 \\
& & $(55.5)$ & $(26.8)$ & $(6.0)$ & $(7.8)$ & $(4.0)$ & \\
3 & Use of Radio and & 251 & 73 & 37 & 18 & 21 & 4.285 \\
& Television programmes & $(62.7)$ & $(18.3)$ & $(9.0)$ & $(4.5)$ & $(5.3)$ & \\
& & & & & & & \\
4 & Farmers and Traders & 226 & 100 & 26 & 22 & 26 & 4.055 \\
& Associations & $(56.5)$ & $(25.0)$ & $(6.5)$ & $(5.5)$ & $(6.5)$ & \\
\hline
\end{tabular}


African Journal of Economics and Sustainable Development

ISSN: 2689-5080

Volume 4, Issue 1, 2021 (pp. 63-80)

www.abjournals.org

\begin{tabular}{llcccccc}
\hline & & & & & & \\
\hline 5 & Community Associations & 232 & 98 & 37 & 18 & 15 & 3.078 \\
& & $(58.0)$ & $(24.5)$ & $(9.3)$ & $(4.5)$ & $(3.8)$ & \\
6 & Collaboration with & 211 & 89 & 37 & 37 & 26 & 4.363 \\
& Traditional Councils & $(52.8)$ & $(22.3)$ & $(9.3)$ & $(9.3)$ & $(6.5)$ & \\
7 & Youth and Women & 210 & 105 & 23 & 30 & 32 & 3.628 \\
& groups & $(52.5)$ & $(26.3)$ & $(5.8)$ & $(7.5)$ & $(8.0)$ & \\
8 & Involvement of rural & 157 & 88 & 25 & 109 & 21 & 4.225 \\
& dwellers in governance & $(39.3)$ & $(22.0)$ & $(6.3)$ & $(27.3)$ & $(5.3)$ & \\
\hline
\end{tabular}

The results of analysis on the ways of creating awareness of rural development revealed that collaboration with traditional councils $(\bar{X}=4.363)$. The results further indicated that $62.5 \%$ and $17.5 \%$ of the respondents said to a very large extent and to a large extent respectively, this measure is required. Other ways based on the findings are radio and television programmes $(\bar{X}=4.285)$ and involvement of rural dwellers in governance $(\bar{X}=4.225)$ to a large extent were identified as the major ways of creating awareness on strategies for promoting sustainable rural development in the State. However, public sensitization programmes, community associations, youth and women groups and advocacy visits were also found to be important strategies for creating awareness on sustainable rural development because their mean ratings were statistically greater than 3.0 used as the criterion mean.

Table 3: Challenges facing Sustainable Rural Development Agenda

\begin{tabular}{llcccc}
\hline SN. & Ways of Creating Awareness & N & Mean & Std. Dev. & Ranking \\
\hline 1 & Exclusion of rural dwellers at the planning & 400 & 4.208 & 1.204 & $1^{\text {st }}$ \\
2 & $\begin{array}{l}\text { Absence of needs assessment } \\
3\end{array}$ & 400 & 4.105 & 1.211 & $2^{\text {nd }}$ \\
& $\begin{array}{l}\text { Political instability/frequent change of } \\
\text { government }\end{array}$ & 400 & 3.183 & 1.201 & $9^{\text {th }}$ \\
4 & $\begin{array}{l}\text { Corruption and bad leadership } \\
5\end{array}$ & 400 & 3.760 & 1.273 & $5^{\text {th }}$ \\
6 & Mismanagement of budgetary allocation & 400 & 3.745 & 1.318 & $6^{\text {th }}$ \\
7 & $\begin{array}{l}\text { Rural policy implementation gaps } \\
8\end{array}$ & 400 & 3.820 & 1.229 & $4^{\text {th }}$ \\
& $\begin{array}{l}\text { Absence of human capital development } \\
\text { initiatives }\end{array}$ & 400 & 3.742 & 1.277 & $7^{\text {th }}$ \\
& $\begin{array}{l}\text { Absence of a workable template for } \\
\text { sustainable rural development }\end{array}$ & & & & \\
\end{tabular}

The analysis of challenges facing sustainable development in Table 4 revealed that exclusion of rural dwellers at the planning stage $(\bar{X}=4.208)$ was ranked $1^{\text {st }}$,absence of needs assessment ( $\bar{X}=4.104$ ) was ranked $2^{\text {nd }}$, absence of human capital development framework ( $\bar{X}=3.903)$ was ranked $3^{\text {rd }}$, rural policy implementation $\operatorname{gaps}(\bar{X}=3.820)$ was ranked $4^{\text {th }}$ and corruption and bad leadership $(X=3.760)$ ranked $5^{\text {th }}$ and mismanagement of budgetary allocation for rural development ( $\bar{X}=3.745$ ) was ranked $6^{\text {th }}$. The study also found that lack of 
agricultural inputs $(\bar{X}=3.742)$ which is ranked $7^{\text {th }}$ and absence of a workable template for sustainable rural development $(\bar{X}=3.540)$ which is ranked $8^{\text {th }}$ were all identified as challenges to rural development in Nasarwa State.

Table 4: How Communities can be Involved in Sustainable Rural Development Decisions

\begin{tabular}{|c|c|c|c|c|c|c|c|}
\hline SN & $\begin{array}{l}\text { Rural Development } \\
\text { Decisions }\end{array}$ & TVLE & TLE & NS & TSE & TLTE & $\overline{\mathbf{X}}$ \\
\hline 1 & $\begin{array}{l}\text { Establishing local autonomy } \\
\text { through community } \\
\text { participation }\end{array}$ & $\begin{array}{c}109 \\
(27.3)\end{array}$ & $\begin{array}{c}141 \\
(35.3)\end{array}$ & $\begin{array}{c}56 \\
(27.3)\end{array}$ & $\begin{array}{c}47 \\
(11.8)\end{array}$ & $\begin{array}{c}47 \\
(11.8)\end{array}$ & 3.213 \\
\hline 2 & $\begin{array}{l}\text { Decentralization of } \\
\text { governance by making } \\
\text { development areas functional }\end{array}$ & $\begin{array}{c}148 \\
(35.0)\end{array}$ & $\begin{array}{c}142 \\
(35.5)\end{array}$ & $\begin{array}{c}52 \\
(27.3)\end{array}$ & $\begin{array}{c}38 \\
(9.5)\end{array}$ & $\begin{array}{c}28 \\
(7.0)\end{array}$ & 4.362 \\
\hline 3 & $\begin{array}{l}\text { Developing project } \\
\text { implementation bodies based } \\
\text { on rural realities }\end{array}$ & $\begin{array}{c}147 \\
(36.8)\end{array}$ & $\begin{array}{c}111 \\
(27.8)\end{array}$ & $\begin{array}{c}66 \\
(27.3)\end{array}$ & $\begin{array}{c}44 \\
(11.8)\end{array}$ & $\begin{array}{c}32 \\
(8.0)\end{array}$ & 4.396 \\
\hline 4 & $\begin{array}{l}\text { Maintaining proper } \\
\text { communication channel } \\
\text { between rural dwellers and } \\
\text { their representatives }\end{array}$ & $\begin{array}{c}128 \\
(32.0)\end{array}$ & $\begin{array}{c}164 \\
(41.0)\end{array}$ & $\begin{array}{c}44 \\
(27.3)\end{array}$ & $\begin{array}{c}29 \\
(7.2)\end{array}$ & $\begin{array}{c}35 \\
(8.8)\end{array}$ & 3.765 \\
\hline 5 & $\begin{array}{l}\text { Introducing awards for safe } \\
\text { guarding public goods in } \\
\text { rural communities }\end{array}$ & $\begin{array}{c}139 \\
(34.8)\end{array}$ & $\begin{array}{c}103 \\
(25.8)\end{array}$ & 55 & $\begin{array}{c}41 \\
(10.3)\end{array}$ & $\begin{array}{c}62 \\
(15.5)\end{array}$ & 4.021 \\
\hline 6 & $\begin{array}{l}\text { Contractors of projects } \\
\text { should be source from } \\
\text { communities where they are } \\
\text { to be sited }\end{array}$ & $\begin{array}{c}107 \\
(26.7)\end{array}$ & $\begin{array}{c}152 \\
(38.0)\end{array}$ & $\begin{array}{c}72 \\
(27.3)\end{array}$ & $\begin{array}{c}27 \\
(6.8)\end{array}$ & $\begin{array}{c}42 \\
(10.5)\end{array}$ & 4.640 \\
\hline 7 & $\begin{array}{l}\text { Rural dwellers should be } \\
\text { incorporated in the } \\
\text { supervision of rural projects } \\
\text { in their localities }\end{array}$ & $\begin{array}{l}115 \\
(28.7)\end{array}$ & $\begin{array}{c}133 \\
(33.3)\end{array}$ & $\begin{array}{c}64 \\
(27.3)\end{array}$ & $\begin{array}{c}57 \\
(14.2)\end{array}$ & $\begin{array}{c}31 \\
(7.8)\end{array}$ & 3.987 \\
\hline 8 & $\begin{array}{l}\text { Accountability meetings } \\
\text { should be organize } \\
\text { periodically for political } \\
\text { leaders to give their score } \\
\text { cards }\end{array}$ & $\begin{array}{c}163 \\
(40.8)\end{array}$ & $\begin{array}{c}119 \\
(29.8)\end{array}$ & $\begin{array}{c}52 \\
(27.3)\end{array}$ & $\begin{array}{c}32 \\
(8.0)\end{array}$ & $\begin{array}{c}34 \\
(8.5)\end{array}$ & 4.211 \\
\hline 9 & $\begin{array}{l}\text { Rural dwellers should be } \\
\text { given tax holidays }\end{array}$ & $\begin{array}{c}136 \\
(34.0)\end{array}$ & $\begin{array}{c}52 \\
(13.0)\end{array}$ & $\begin{array}{c}28 \\
(7.0)\end{array}$ & $\begin{array}{c}44 \\
(27.3)\end{array}$ & $\begin{array}{c}41 \\
(10.3)\end{array}$ & 3.458 \\
\hline
\end{tabular}

The results of analysis of how communities can be involved in sustainable rural development in Table 5 showed that contractors of projects should be sourced from communities where they are to be $\operatorname{sited}(\bar{X}=4.640)$,developing project implementation bodies based on rural realities $(\bar{X}=4.396)$,decentralization of governance by making development areas functional 
( $\bar{X}=4.362$ ), accountability meetings should be organize periodically for political leaders to give their score cards $(\bar{X}=4.211)$, introducing awards for safe guarding public goods in rural communities $(\bar{X}=4.021)$ respectively. They argued that to a large extent if these strategies are adopted, sustainable rural development will be achieve in Nasarawa State. However, the stated further that measures such as incorporating rural dwellers in the supervision of rural projects in their localities,establishing local autonomy through community participation, maintaining proper communication channels between rural dwellers and their political representatives and the granting of tax holidays to rural dwellers among others will also contributing significantly in making them participate in rural development decisions in the State.

Table 5: Workable Strategies Necessary for Sustainable Rural Development

\begin{tabular}{llcccc}
\hline SN & Strategies Adopted & N & Mean & Std. Dev. & $\overline{\mathbf{X}}$ \\
\hline 1 & Bottom-top approach to planning & 400 & 4.413 & 1.180 & $1^{\text {st }}$ \\
2 & Participation of rural dwellers in decision & 400 & 4.280 & 1.221 & $3^{\text {th }}$ \\
& $\begin{array}{l}\text { making } \\
3\end{array}$ & & & & \\
4 & Modernization of agriculture and rural economy & 400 & 4.223 & 1.169 & $5^{\text {th }}$ \\
& Economic empowerment of rural youth and & 400 & 4.375 & 1.094 & $2^{\text {nd }}$ \\
& women & & & & \\
5 & Provision of infrastructural/social amenities & 400 & 4.221 & 1.214 & $6^{\text {th }}$ \\
6 & Greater investment in human capital & 400 & 4.232 & 1.208 & $4^{\text {rd }}$ \\
& development & & & & \\
7 & Promoting industrialization in rural areas & 400 & 3.208 & 1.208 & $9^{\text {th }}$ \\
8 & Supporting rural innovators and entrepreneurs & 400 & 4.219 & 1.276 & $7^{\text {th }}$ \\
9 & Enhancing human and food security in rural & 400 & 3.548 & 1.320 & $8^{\text {th }}$ \\
& areas & & & & \\
\hline
\end{tabular}

The analysis of workable strategies for sustainable development in Table 6 indicated that Bottom-top approach to planning $(\bar{X}=4.413)$,economic empowerment of rural youth and women( $\bar{X}=4.375$ ), participation of rural dwellers in decision making $(\bar{X}=4.280)$, greater investment in human capital development $(\bar{X}=4.232)$. The study found the need for the provision of infrastructural/social amenities $(X=4.221)$, supporting rural innovators and entrepreneurs $(\bar{X}=4.219)$,enhancing human and food security in rural $\operatorname{areas}(\bar{X}$ $=3.548)$, provision of infrastructural/social amenities in rural areas $(X=3.530)$ among others as important strategies since their mean were statistically greater than 3.0.

\section{Discussion of Findings}

Rural development has attracted of successive governments of most States in Nigeria. This study therefore examines the strategies for rural development in Nasarawa State. The findings on the of the extent of the implementation of sustainable rural development strategies in the State the major rural development strategies that have been implemented in the State focused 
on revealed agricultural development and social services. Buttressing this, Otive (2006) opined that people living in the rural areas are poor and suffer hunger because the economies at this level mainly depend on agriculture. The findings further showed that successive government have shown less attention on rural infrastructural development, human capital development, environmental resources protection, political inclusion, industrial growth and poverty reduction/economic empowerment programmes. This is consonance with the view of Adenipekun (2013) argued that Government with a view to alleviating the imbalance between rural and urban development took certain policy measures that rather further accentuate the skewed and imbalanced situation.

Similarly, the findings on ways of creating awareness on rural development in the State revealed to a large extent, collaboration with traditional councils, creating awareness through radio and television programmes, involvement of rural dwellers in governance are important and results oriented strategies for creating awareness of sustainable rural development. Most of the respondents maintained that public sensitization programmes through community associations, youth and women groups and advocacy visits are other ways of creating awareness on sustainable rural development in Nasarawa State. This supported the view of Akhimien, Adamolekun and Isiwele (2016) who pointed out that for sustainable rural development, the local government is to create wider opportunities for individuals to realize their full potentials through education and sharing in the decisions and actions which affect their lives.

Furthermore, the findings on the challenges facing sustainable rural development in the State revealed that to a large extent, the exclusion of rural dwellers at the planning stage, absence of needs assessment, absence of human capital development framework, rural policy implementation gaps and corruption and bad leadership and mismanagement of budgetary allocation for rural development, lack of agricultural inputs and absence of a workable template for sustainable rural development are the major challenges to sustainable rural development in Nasarwa State. This agreed with the view of Adenipekun (2013) who pointed out that development of rural areas is measured by the provision of infrastructures and economic opportunities made available to the people. The situation in Nigeria is abysmally poor and has constituted one good source of poverty. Ainebyona (2014) noted that rural industries are mainly agricultural based and labour intensive, thus difficult to introduce sophisticated techniques and methods of production which are expensive and there is no technical know how to run them.

The findings on how communities can be involved in sustainable rural development decisions in the State revealed that government and development partners should ensure that contractors of projects should be source from communities where they are to be sited, developing project implementation bodies based on rural realities, decentralization of governance by making development areas functional, accountability meetings should be organize periodically for political leaders to give their score cards, introducing awards for safe guarding public goods in rural communities. In the light of this, Adenipekun (2013) asserted that a framework of integrated developments that incorporates the growth poles model of city development and that of integrated-local-endogenous development is very imperative.

The research also revealedincorporating rural dwellers in the supervision of rural projects in their localities, establishing local autonomy through community participation, maintaining 
proper communication channels between rural dwellers and their political representatives and the granting of tax holidays to rural dwellers the contributions of rural dwellers in sustainable rural development decisions in the State can be enhanced. Aheibwe (2013) stated that rural development cannot take place simply as a result of empowerment of the poor through supporting self-reliance and underlining popular participation par se but by addressing the obstacles faced by the rural poor such as inappropriate policies, missing or uncompetitive markets, weak rural infrastructure, inadequate processing opportunities and financial services. Akhimien, Adamolekun and Isiwele (2016) rightly maintained that an increasing number of rural communities are looking for development approaches beyond the conventional dispersed land use patterns that make it difficult for them to meet their fiscal, social, public health, and environmental goals.

More so, the findings on workable strategies for sustainable rural development in the State revealed that respondents suggested the need for the adoption of bottom-top approach to planning, economic empowerment of rural youth and women,increase participation of rural dwellers in decision making and greater investment in human capital development. The study also posited that theprovision of infrastructural/social amenities, supporting rural innovators and entrepreneurs and enhancing human and food security in rural areas to a large extent are strategies that should be included in designing a workable template or blue print for sustainable rural development in Nasarawa State. This supported the view of Aledare and Okesoto (2010), that the main policy thrust on food security in the 7-point presidential agenda includes "the injection into research, production and development of agricultural inputs, to revolutionize the agricultural sector, leading to 5-10 folds increase in yield and production, resulting in massive domestic and commercial outputs and technological knowledge transfer to farmers .Similarly,Olaseni and Alade (2012) reported that Vision 20:2020 was generated from the outcome of a research by the American Investment Bank on the prospects of Nigeria becoming a nation in the league of 20 topmost economies of the world if the nation's abundant natural and human resources could be effectively managed.

\section{CONCLUSION}

This research examined the strategies for sustainable rural development in Nasarawa State. The findings from the empirical analysis revealed that government agricultural development and social services provisions have been the major rural development strategies that have been implemented in the State. The findings showed that less attention has been given to human capital development, political inclusion, infrastructural development and industrial growth. It was found that radio and television, farmers and traders association and collaboration with traditional councils are ways of creating awareness on sustainable rural development. However, exclusion of rural dwellers at the planning stage and absence of rural needs assessment were found to be the major challenges to sustainable rural development in the State. Thus, to enhance the involvement of rural people in sustainable development decisions, the respondents said contractors of projects should be source from communities where they are to be sited and development programmes should be based on rural realities, and a workable strategy for rural development should emphasis the bottom-top approach, empowerment of youth and women an greater investment in human capital development. The study concluded that strategies for rural development of Nasarawa State have not been 
African Journal of Economics and Sustainable Development

ISSN: $2689-5080$

Volume 4, Issue 1, 2021 (pp. 63-80)

www.abjournals.org

effectively designed and implemented because the emphasis has always been on agriculture only.

\section{RECOMMENDATIONS}

Based on the findings of this study and the conclusion drawn, the following have been recommended as was of achieving sustainable rural development in the study Area:

i. Government should always embark on rural development needs assessment before formulating and implement sustainable rural development programmes in the State

ii. Sustainable rural development policy in Nasarawa State should be limited to agriculture and infrastructure, greater emphasis should be on human capital development and rural entrepreneurial initiatives /programmes

iii. Government should ensure that rural dwellers are involved in rural development policy and programmes right from the planning stage for sustainable rural development in the State

iv. Government and non-government organizations should use diverse means of creating awareness on sustainable rural development decisions and the role of rural dwellers.

\section{REFERENCES}

Abraham, H. \& Balogun, I. O. (2012). Contribution of Microfinance to GDP in Nigeria: Is there any? International Journal of Business and Social Science,3(17),167-176.

Adenipekun, M.T. (2010). "Conservation of Natural Resources in Nigeria: A pragmatic solution to socio-economic and environmental crisis. Apaper presented at the 2010 National Conference of the Department of Estate Management, Yaba College of Technology, August

Adenipekun, M.T. (2013). Sustainable Rural Infrastructural Development in Nigeria within thecontext of Vision 20:2020. International Journal of Development and Sustainability, 2(1), 254-269.

Aheibwe, G. (2013). Youth Engagement in Agriculture in Uganda.Uganda: Ministry of Trade, Industry and Cooperatives.

Ainebyona,D., (2014). National Industrial Policy for Uganda.A Framework for Uganda"sTransformation,Competitiveness and prosperity. Uganda: Ministry of Trade, Industry and Cooperatives.

Akinola, S.R.(2008). Coping with social deprivation through self-governing institutions in oil communities of Nigeria. Africa Today,55(1),89-107.

Akpomuvie, B.O. (2010). Self-help as a Strategy for Rural Development; A bottom- up Approach. Journal of Perspective in Social Science,2(1),88-111

Amiolemen, S. O. \&Adegbite, A. (2012). Sustainable development policy and corporate social responsibility in business organizations in Nigeria. Social Science Research Network. Retrieved from http://papers.ssrn.com/sol3/papers.cfm?abstract_id=1991771 
Awojobi,A.O.(2014).Sustainable rural development in Nigeria within the context of the Millennium Development Goals.International Journal of Contemporary Applied Sciences, 1(1),58-74

Boser U.,(2014). Return on education investment: A district-by-district evaluation of US educational productivity. Centre for American progress. Available online: http://cdn.americanprogress.org/wp-content/uploads/2014/07/ROI-report.pdf

Cawley, M. \& Gillmor, D. A. (2008). Sustainable rural system. England: Ashgate

Christofakis, M. \&Papadaskalopoulos, A. (2011). The growth poles strategy in regional planning: The recent experience of Greece:Theoretical and Empirical Researches in Urban Management, 6(2),5-7.

Christofakis, M. (2001). “Local development and regional policy”.Athens:Papazisis

Herman E.D.(2017) Trump's Growrhism: Its roots in neoclassical economics theory. Retrieved from https:// prndopopulus.com/blog/trums-grothism-its-roots-in-neoclassical -e economic-theory/ on 12/11/2020

Laah, D. E., Abba, M., Ishaya, D. S. \&Gana, J. N. (2013).The mirage of rural development in Nigeria. Journal of Social Sciences and Public Policy,5(2),34-39

Mirakhor, A. \&Askari, H. (2010).Islam and the path to human and economic development.New York: Palgrave Macmillan

Nalere, P.,Yago. M. \& Oriel.K.(2015).The contribution of rural institutions to rural development: Study of smallholder farmer groups and NGOs in Uganda.International NGO Journal, 10(14),37-51

Nyagba, S. (2009).Review of Nigeria's rural development policy for sustainable growth. Presentation at the West African Regional Conference on Smart, Appropriate Technologies for Rural Communities, Abuja, Nigeria, July 9-11

Olaseni, M. and Alade, W. (2012). "Vision 20:2020 and the Challenges of Infrastructural Development in Nigeria", Journal of Sustainable Development, 5(2), 63-66.

Olayiwola, L. M. \&Adeleye, O. A. (2005). Rural infrastructural development in Nigeria: Between 1960 and 1990-problems and challenges. Journal of Social Science,11(2),9196

Oluseyi,O. (2018).Assessment of rural development strategy in Nigeria: Lessons from the past. Journal of Humanities And Social Science), 23( 9), 01-10

Peers C., (2015). What is "human in human capital theory? Making a transition from industrial to post-industrial education.Open Rev. Educ. Res. 2(1),55-57

Prus, P. (2002). The possibilities of applying the concept of sustainable development on family farms. Annals of Science, 5(5), 124-128.

Raheem, W.M. \&Bako, A.I.(2014). Sustainable rural development programmes in Nigeria: Issues and challenges. Asian Journal of Science and Technology, 5 (9),577-586

Todaro, M. (2008). Economic development: USA, Addison Wesley

Williams, S. K. T. (1994). Issues and priority in agricultural extension in Nigeria in the $21^{\text {st }}$ century. Keynote AddressPresented at the Maiden Conference of Society forNigerian Agricultural Extension. ARMTI, llorin, February 28 - March 4

World Bank (2011). World Development Report 2012: Gender equity and development. Washington, DC: The World Bank. 